\title{
A New Cost-Profit Model for Measuring the Optimal Scale of China's Foreign Exchange Reserve
}

\author{
Xing $\mathrm{Li}^{1}$ and Tianhai $\operatorname{Tian}^{2}$ \\ ${ }^{1}$ School of Finance, Zhongnan University of Economics and Law, Wuhan 430073, China \\ ${ }^{2}$ School of Mathematical Sciences, Monash University, Melbourne, VIC 3800, Australia \\ Correspondence should be addressed to Xing Li; smillee@163.com and Tianhai Tian; tianhai.tian@monash.edu
}

Received 30 January 2016; Accepted 20 June 2016

Academic Editor: Xiaodong Lin

Copyright (c) $2016 \mathrm{X}$. Li and T. Tian. This is an open access article distributed under the Creative Commons Attribution License, which permits unrestricted use, distribution, and reproduction in any medium, provided the original work is properly cited.

\begin{abstract}
The fast increase of foreign exchange reserve in developing countries has raised a number of important financial questions in recent years. The analysis of the optimal scale of the foreign exchange reserve can provide important indicator to measure the strength and stability of country's financial standing. In this work we propose a cost-profit model and use the financial data during 2000 to 2008 to analyze the optimal scale of China's foreign exchange reserve. We identify a number of financial factors to measure the cost and profit of holding the reserves. Our prediction suggested that China's foreign exchange reserves were still within the moderate range in 1999-2001. However, during 2002-2008 the foreign exchange reserve began to exceed the appropriate scale, and this upward trend was accelerated each year.
\end{abstract}

\section{Introduction}

During the last decade, there has been a sharp increase in the foreign exchange reserve globally from US $\$ 2$ trillion in December 2000 to US $\$ 11$ trillion in April 2013. This increase is dominantly driven by the massive reserve accumulation by the developing countries [1]. In particular, China's foreign exchange reserve was increased from US $\$ 0.16$ trillion in 2000 to US $\$ 3.55$ trillion in July 2013. This steep increase renders the international reserve an important factor to represent the ability of international discharging of a country as well as an important index to inspect the financial strength and credit standing of a country. The foreign exchange reserve also plays an important role in maintaining the payment ability of a country in foreign trade, stabilizing the foreign exchange market, guaranteeing the repayment of foreign loans, and resisting the influence of financial crisis [2]. However, these benefits come at a cost. Since the majority of reserves are invested in US treasuries, the modest return from the US Treasure is much lower than the borrowing costs of a government in either local or foreign currencies [3]. In addition, if a country holds much more foreign exchange reserve than needed, any change in finance and in politics, such as the decrease of interest rate, appreciation of local currency, and difficulties of managing the reserves, will cause serious problems that may lead to financial losses. This excessive reserve accumulation also leads to prolonged global economic imbalance due to Triffin's Dilemma. Thus, there is a strong need to manage the foreign exchange reserve at a moderate and appropriate scale [4].

In China, the massive amount of foreign exchange reserve is an even more complex issue [5]. Since the economic reform in 1979, the world has been marveling at the rapid economic development of China. In particular, the foreign exchange reserve has been increasing continuously and rapidly after 1994. From 1994 to 2008, the foreign exchange reserve has increased almost 37 times with an annual increase rate of $37.9 \%$. In 2006 the foreign exchange reserve of China surpassed that of Japan and jumped to the first of the world with a total amount of US\$1.94 trillion. China's foreign exchange reserve also faces the management problem of a moderate scale [6]. In particular with the facts of current changing international political and economic situations, the devaluation of US dollar, and the instability of international currency system, much broader and deeper management requirements are aroused for the scale of China's foreign exchange 
reserve [7]. Thus, how to determine a moderate scale of China's foreign exchange reserve and how to improve the usage and management of the reserve assets have become an important question of the system reforming of China's foreign exchange management [8].

A number of research methods have been proposed to analyze the scale of the optimal foreign exchange reserve from different aspects. The ratio analysis method explores the corresponding ratio results by comparing the scale of foreign exchange reserve with one or several financial factors, such as import, foreign debt, or GDP. This method was first proposed in 1960 to derive the ratio of foreign exchange reserve and import [9]. However, this simple method ignores other important financial factors such as capital flow and capital account. Since the 1980s, a number of factors have been proposed to be included in this methodology, such as the external debt, short-term debt, and broad money supply [10]. In addition, Jeanne proposed a method for the small-scale opening economies to obtain the optimal level of foreign exchange reserve against the gross domestic product (GDP) [11]. Although the ratio analysis method is concise and easy to implement, its economic foundation is still lacking theoretically.

The cost-profit analysis method is based on the theory of maximizing the benefits of limited cost, which was first proposed in 1966 [12]. Heller defined the profit as holding foreign exchange reserve against economic losses caused by the expenditure-changing policies such as recession and rising unemployment and the cost as the difference between the income from investing the reserve in other financial assets and that from the foreign exchange reserve itself. The costprofit analysis method has a precise economic foundation but still has a few paradoxes in empirical studies. The key issue in using this method is to identify key factors that may be related to either the costs or profits. However, the influence of some factors is still a little uncertain. Thus, recent studies indicated that a number of other manifestations of profit may be also related to the cost-profit model. The third type of method is the regression analysis, which constructs the demand function of foreign exchange reserve based on a number of variables that are related to the reserves and then uses the multiple regression and correlation analysis to determine a stable demand function. This analysis method has had further developments after the 1990s, especially for the analysis of holding foreign exchange reserves in developing economies. Jeanne confirmed that one of the motivations of the emerging economies holding foreign exchange reserves is to prevent the capital account crisis [11]. However, regression analysis is mainly used to study the foreign exchange reserves from the point of view of demand, namely, the internal economy demand and foreign economic demand. It is difficult to use this method to analyze intervention motivations and the impact of intervention on the comprehensive national strength values, especially for a country which uses foreign exchange reserves to intervene in the foreign exchange market $[13,14]$. In addition, this method does not consider the cost of holding foreign reserve. Thus, our cost-profit analysis method is more appropriate to analyze the foreign exchange reserve comprehensively by taking more factors into account.
Considering the special situation of China's foreign exchange reserve, this paper employs the cost-benefit analysis approach to construct a model of the optimal scale of the foreign exchange reserve and then measure the modest scales under different amount of the GDP. Since the outbreak of the global financial crisis in 2008, the relevant financial data are quite different before or after 2008. For the situation after 2008, basically years 2008-2010 can be regarded as a time period of emergency phase of the financial markets. The financial market was relatively stabilized in 2010-2014. A potential new model should be developed to study the foreign exchange reserve in this time period, though this time period is relatively short. Since the purpose of foreign exchange market intervention in China was mainly to prevent excessive appreciation of Chinese Yuan before 2015, but to avoid accelerated devaluation after 2015, the foreign exchange rate fluctuated substantially during this time period. Therefore, we need to separate the Chinese foreign reserve data in the time period before 2008 from those after 2008. In this work we avoid the financial data after 2008 and pay special attention to the data from 2000 to 2008 . We first identify the factors related to costs and profits in Sections 2 and 3, respectively, and then develop the cost-profit model for the optimal scale of China's foreign exchange reserve in Section 4.

\section{Costs of Holding Reserves in China}

The costs of holding international reserves in China are classified into two major categories: the cost of interest losses and that due to the changes of foreign exchange rates. We will discuss these two types of costs below.

2.1. Cost of Interest Loss. The first principle in managing foreign exchange reserves is to ensure the liquidity of the reserves. However, sufficient liquidity will give up the profit, which is called the cost of interest losses. This type of cost is mainly measured by the interest income of the short-term deposit in a bank, which is assumed as the income if the reserve is not liquidated. Note that other interest incomes, such as the long-term deposit in a bank, mainly stand for the profit of holding foreign exchange reserves and are not classified into the cost of holding the reserves.

Since about $80 \%$ of China's foreign exchange reserves are in US dollar, the cost of interest losses is mainly based on the short-term interest rate of US dollar in the international financial market. With the development of offshore financial market since the 1960s, it has been regarded as a highly free, efficient, and convenient market for capitals. The profit of investors in this market is fully protected. For the short-term investment, the interest rate in the offshore financial market is higher than that provided by an independent country. Thus, we assume that the loss of interests is the interest rate of the short-term Euro-dollar deposit of 3 months in the offshore financial market in Europe. To avoid the major fluctuations in the world economy, as indicated in Section 1, we use the data of interest rate from 2000 to 2008 in Figure 1, from which we obtain the averaged interest rate of Euro-dollar's 3-month deposit that is $3.574 \%$. 


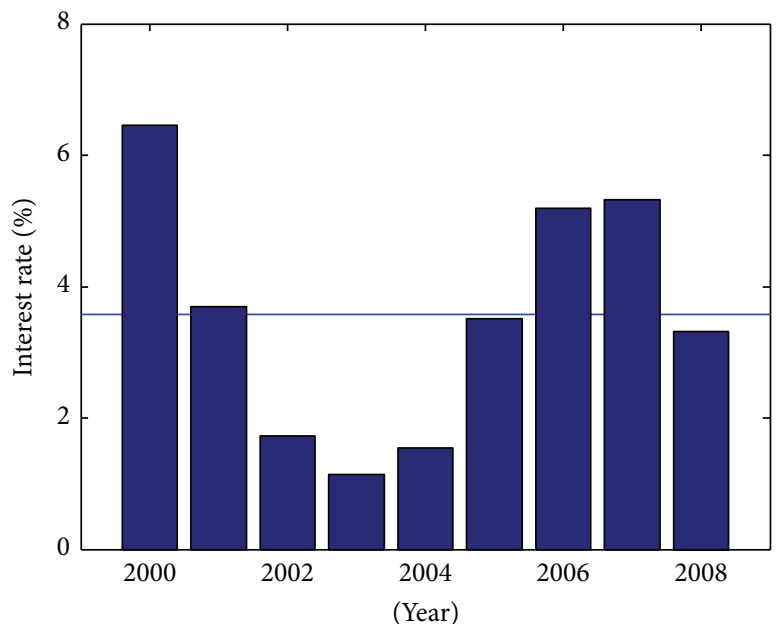

(a)

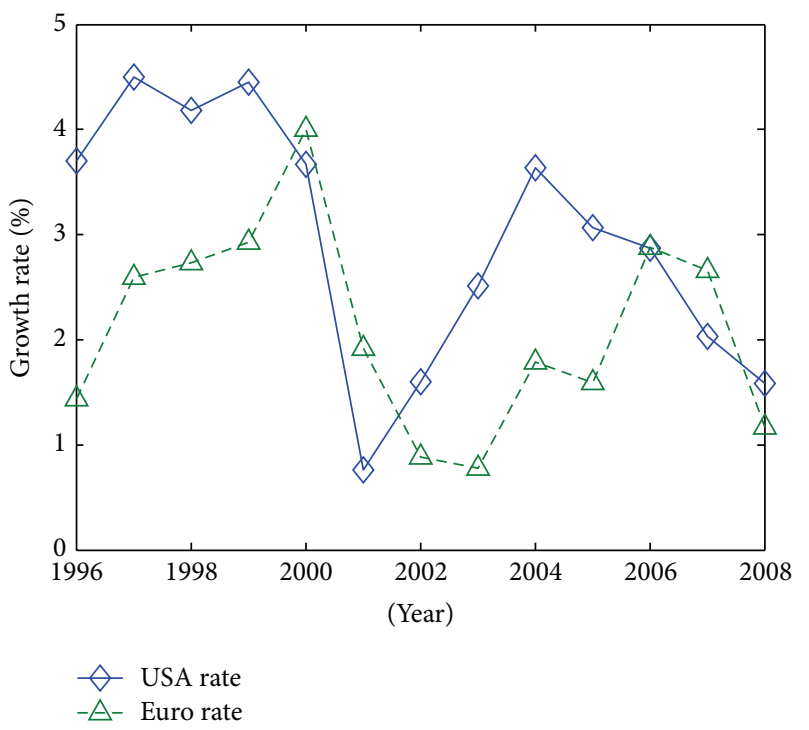

(b)

FiguRE 1: (a) The interest rate of Euro-dollar's 3-month deposit from 2000 to 2008. The horizontal line is the averaged interest rate 3.574\% (resource: statistical data of the US Federal Reserve Bank). (b) The GDP growth rate of the US (solid-line) and Eurozone (dash-line) (unit: \%) (source: World Economic Outlook, IMF).

TABLE 1: Fluctuations of US dollar exchange rate.

\begin{tabular}{lcccc}
\hline & $\begin{array}{c}\text { USD index against major } \\
\text { currencies }\end{array}$ & $\begin{array}{c}\text { Devalued rate of USD to } \\
\text { major currencies }\end{array}$ & $\begin{array}{c}\text { Exchange rate } \\
\text { against RMB }\end{array}$ & $\begin{array}{c}\text { Devalued rate of } \\
\text { USD to RMB }\end{array}$ \\
\hline 1999 & 94.06 & - & 8.28 & 8.28 \\
2000 & 98.34 & - & 8.28 & - \\
2001 & 104.26 & - & 8.28 & - \\
2002 & 106 & 0.12 & 8.28 & - \\
2003 & 93 & 0.08 & 8.28 & - \\
2004 & 85.37 & 0.02 & 8.19 & 0.01 \\
2005 & 83.71 & 0.01 & 7.97 & 0.03 \\
2006 & 82.46 & 0.06 & 7.61 & 0.05 \\
2007 & 77.84 & & 6.95 & 0.08 \\
2008 & & 0.06 & & 0.04 \\
\hline Mean & & & & \\
\hline
\end{tabular}

Source: statistical data, the United States Federal Reserve; WDI, excerpted from 2008-2009 Yearbook of World Economy published in China.

2.2. Cost of Exchange Rate. When holding foreign exchange reserves, their value may be affected by the change of foreign exchange rates. The loss of its value due to depreciation of the reserves is termed the cost of exchange rate. Since the Jamaica Agreement in 1978 that admits the legalization of floating exchange rates, the system of floating exchange rate has let the values of a number of key currencies, such as USD, EUR, GBP, and JPY, fluctuate over time. Because of the dominant importance of USD in China's reserves, we focus on the changes of USD value that reflect the changes of exchange rate in China.

Since the 1990s, in particular after 1995, the economic growth was accelerated in a number of developed countries. In particular, the economy was expanded quickly in the United States due to the fast development of information technology (IT). However, after the 21st century, economic growth was weakened because of the universal of computer and communication technologies (see Figure 1(b)). The consequence of a weak US economy is the depreciation of US dollar. In 2008, due to the US subprime mortgage crisis and the following global financial crisis, the dollar devalued sharply, which made China face potential huge cost of exchange rate.

We use the US dollar exchange rate during 2000 2007 in Table 1 to analyze the cost of exchange rate. The US dollar depreciated about $6 \%$ on average against the other major currencies. Since 2005, China has gradually liberalized the movement of exchange rate. The exchange rate of US dollar against the RMB has dropped from 8.28 in 2004 to 7.61 in 2007. The averaged rate of depreciation during this time 
period is about $8 \%$. Considering US dollar continued the trend of depreciation after the global financial crisis in 2008, we use the averaged depreciation rate of $8 \%$ to conduct the analysis.

In summary, the cost of interest loss and cost of exchange rate are the major types of costs for holding China's foreign exchange reserves. It is worthy of note that there are a number of other types of costs, such as the management cost for the reserve diversification and cost of impact on the domestic economy that may increase the broad money supply, domestic price level, and asset prices, as well as even affecting the domestic economic structure. However, it is difficult to quantify these changes and their consequent influence. Thus, these factors will not be considered in this work.

\section{Profit of Holding Reserves in China}

The profit of holding foreign exchange reserves derives from the demanding motivations of reserves. There are three major categories of motivations, namely, the motivation of productive investment, motivation of intervention in response to the need, and motivation of making profits. Accordingly, our analysis of the profit will be based on these three categories.

3.1. Profit of Productive Investment. For a developing country, the economy is still at the initial developmental stage, and social capitals are in the process of accumulation. There is a strong need to improve the levels of productivity and efficiency constantly and rapidly. Thus, the various investment demands are enormous. The requirement of investment comes from the domestic market and international market. Here the domestic requirement mainly depends on the import and utilization of foreign capitals. The import involves the payment issues of imported foreign products, while the utilization of foreign capitals involves the issues related to investment profit of foreign capitals and debts of external funding. To guarantee the external payment ability, a country must hold a certain amount of foreign currency reserve. Thus, the profit of holding the reserves is the income of investment. Since the quantity of import services and FDI profit repatriation is not big, in this work we analyze the profit related to China's general trade import and foreign debt.

3.1.1. General Trade Imports. The general trade import in China has maintained a growth rate of $12 \%$ or above since 1998, from $>100$ billion in 2000 to $>570$ billion in 2008 (Figure 2(b)). In particular, the year-on-year growth rate reached $49.3 \%$ in 2000 (Figure 2(c)). To guarantee the need of import payment, according to international convention, a country's foreign exchange reserve should ensure at least $20 \%$ of import payments. When we divide $20 \%$ of China's import of each year in Figure 2(b) by the foreign exchange reserve at the same year in Figure 2(a), we obtain the ratio of foreign exchange reserves to import payment. After excluding the influence of the financial crisis in 2008, the averaged proportion over this time period is 0.08 (Figure $2(\mathrm{~d})$ ).

3.1.2. External Debt. Due to the low level of economic opening to the world, China's transaction with the world before the 1990s was relatively conservative. Thus, the amount of foreign debt is not large. Although the balance of foreign debt increased gradually, it was always kept under $\$ 50$ billion. Since the rapid economic development and economic opening to the world, the annual debt balance increased dramatically during the years 2003 2007 with growth increment over $\$ 20$ billion per year (Figure 2(e)). The external debt was largely borrowed for domestic production and investment. To guarantee the repayment of capitals and interests, it is widely accepted that the foreign exchange reserve of a country should be at least $30 \%$ of the foreign debt balance. When dividing $30 \%$ of foreign debt balance of each year by the foreign exchange reserve at the same time, we obtain the ratio of foreign exchange reserve to the foreign debt repayment. Again, to exclude the influence of global financial crisis in 2008, the averaged ratio during 2000 and 2008 is $15 \%$ (Figure 2(f)).

3.1.3. Combination Analysis. When considering China's import and external debt together, the ratio of foreign exchange reserve to meet the import requirement is $8 \%$ and ratio to meet the external debt is about $15 \%$. Thus, these two factors account for the ratio of foreign exchange reserve which is $\sim 23 \%$. When considering the profit of holding reserves, we should focus on the return rate of domestic investment in China. From Table 2, the averaged rate of return on investment is 0.283 based on the yearly averaged capital-output ratio during 1996 and 2008 in China.

When considering the rate of return on investment, domestic inflation rate is a very important factor and should be used to adjust this rate of return. Let $\sigma$ be the rate of return on investment, let $e$ be the foreign exchange rate, let $\mu$ be the coefficient for adjusting the rate of return on investment by the domestic inflation rate, let $R$ be the country's foreign exchange reserves, and let $k$ be the money multiplier. The growth of foreign exchange reserves will lead to an increase of the base currency supply, while the growth of money supply will lead to the rise of inflation. When a country increases the holding of foreign exchange reserve, the base currency will increase as $R * e$. When the currency gets into circulation, it will be enlarged to the supply as $R * e * k$. Assume that the inflation rate will increase by $v$ percent when the broad money supply $\left(M_{2}\right)$ is increased by one percent. Then, when the broad money growth is $R * e * k / M_{2}$ percent, the inflation rate will increase by $v *\left(R * e * k / M_{2}\right)$ percent. Therefore, the coefficient for adjusting the rate of return on investment by the domestic inflation rate is calculated by

$$
\mu=1+\frac{v * R * e * k}{M_{2}},
$$

and then the rate of return on investment is adjusted as $\sigma \mu$. Table 3 gives the data for the based currency supply, broad money supply, and inflation rate. The money multiplier $k$ in Table 3 is calculated using China's broad money supply divided by the amount of base currency supply.

3.2. Profit of Meeting Intervention Motivation. When a financial market or foreign exchange market has experienced 


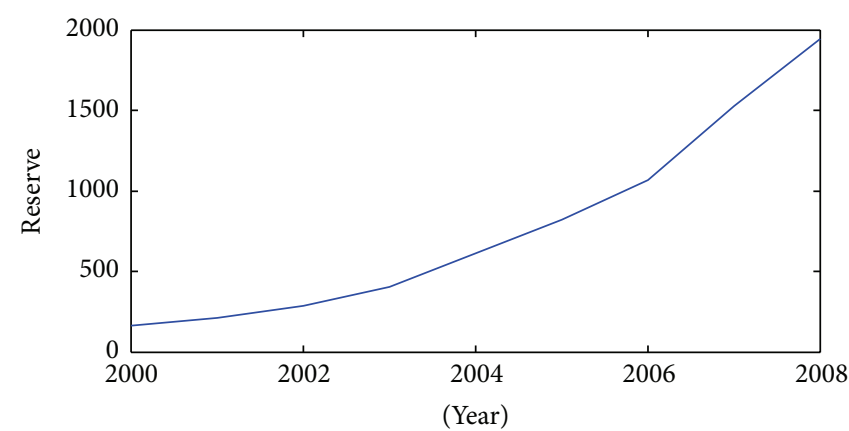

(a)

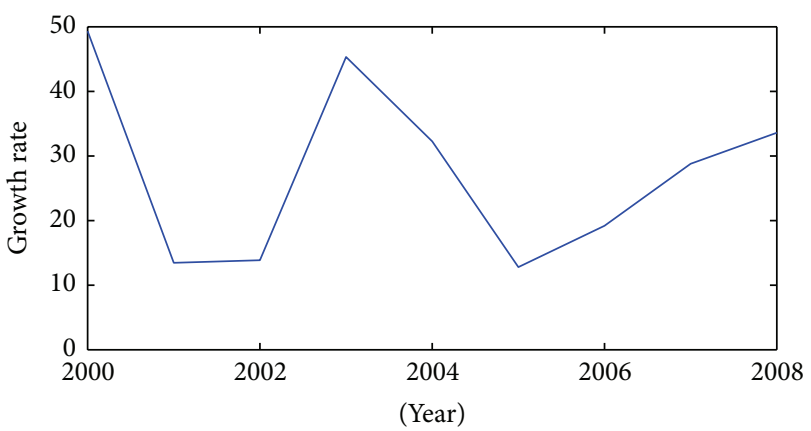

(c)

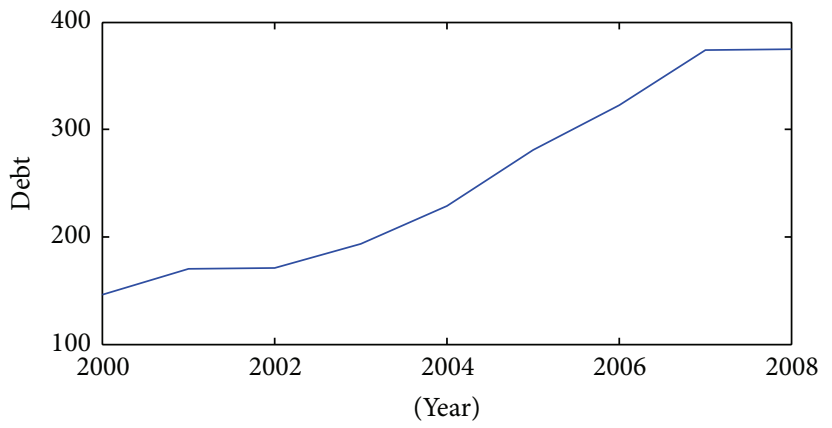

(e)

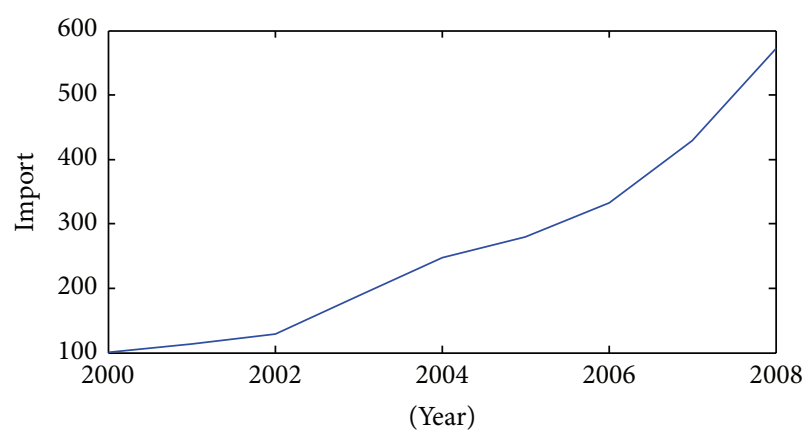

(b)

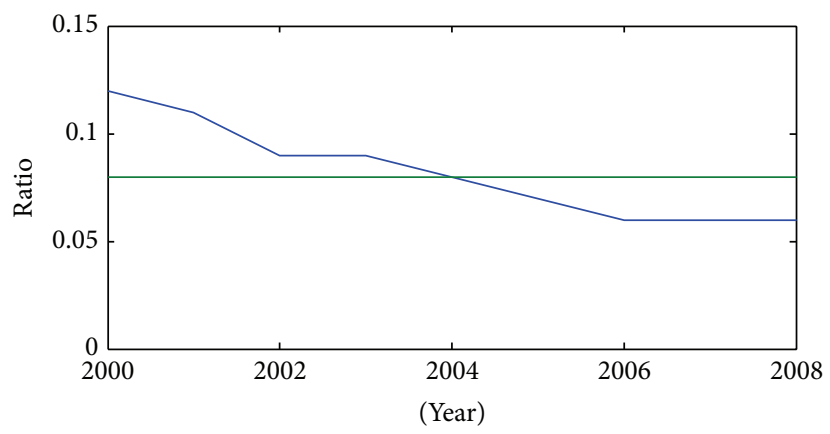

(d)

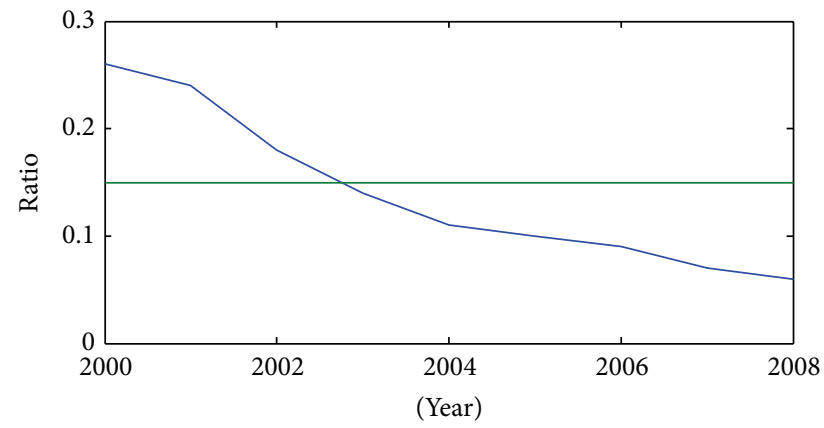

(f)

Figure 2: Relationship between import, debt, and foreign exchange reserve. (a) Foreign exchange reserve (unit: billion). (b) The import of each year in China (unit: billion). (c) Growth rate of foreign import (unit: \%). (d) Ratio of $20 \%$ of import to foreign exchange reserve. The horizontal line is the averaged ratio, $8 \%$ (source: statistical database of the Chinese economic network). (e) Debt of each year in China (unit: billion). (f) Ratio of $30 \%$ of debt to foreign exchange reserve. The horizontal line is the averaged ratio, 15\% (source: Chinese State Administration of Foreign Exchange).

significant volatility, in particular, during the financial crisis, it may cause major influence on the economic performance of a country. To timely intervene the financial market, the monetary authorities of a country need the foreign exchange reserve to cushion the impact of financial volatility on the domestic economy. This intervention is also called the preventive motivation, and the direct benefit of intervention is a type of profit of holding the foreign exchange reserve. Therefore, a country must hold a certain amount of foreign exchange reserve as the capital guarantee to prepare any intervention in order to stabilize the economic environment.

However, it is difficult to determine the appropriate amount of reserves for effective intervention. This amount should be decided by a number of factors and may be different to every country. For China, we refer to the situation of Hong Kong during the Asian financial crisis in 1997 as the test case. At that time, the Administration in Hong Kong used US $\$ 15$ billion of the US\$90 billion foreign exchange reserves to stabilize the financial market. From this instance, we estimated that the amount of reserves for intervention should be in a ratio of $17 \%(=150 / 900)$ of the foreign exchange reserve.

Regarding the benefit of intervention, the direct gain is a stable foreign exchange market, which is connected to a steady domestic market and even to the healthy economic development of the country. Therefore, the ultimate benefit 
TABLE 2: Fluctuations of US dollar exchange rate.

\begin{tabular}{|c|c|c|c|c|}
\hline & Capital (billion) & GDP (billions) & Increment of GDP (billion) & Ratio of output to capital $(\sigma)$ \\
\hline 1995 & & 6321.69 & & \\
\hline 1996 & 2291.35 & 7416.36 & 1094.67 & 0.478 \\
\hline 1997 & 2494.11 & 8165.85 & 749.49 & 0.301 \\
\hline 1998 & 2840.62 & 8653.16 & 487.31 & 0.172 \\
\hline 1999 & 2985.47 & 9096.41 & 443.25 & 0.148 \\
\hline 2000 & 3291.77 & 9874.90 & 778.49 & 0.236 \\
\hline 2001 & 3721.35 & 10897.24 & 1022.34 & 0.275 \\
\hline 2002 & 4349.99 & 12035.03 & 1137.79 & 0.262 \\
\hline 2003 & 5556.66 & 13639.88 & 1604.85 & 0.289 \\
\hline 2004 & 7047.74 & 16028.04 & 2388.16 & 0.339 \\
\hline 2005 & 8877.36 & 18869.21 & 2841.17 & 0.320 \\
\hline 2006 & 10999.82 & 22165.13 & 3295.92 & 0.300 \\
\hline 2007 & 13732.39 & 26309.38 & 4144.25 & 0.302 \\
\hline 2008 & 17229.11 & 30685.98 & 4376.6 & 0.254 \\
\hline Averag & & & & 0.283 \\
\hline
\end{tabular}

Source: Chinese statistical abstract 2009.

TABLE 3: Money multiplier and broad money supply ( $r 1 \%$ : increasing rate of $M_{2} ; k$ : money multiplier; $r 2 \%$ : inflation rate).

\begin{tabular}{|c|c|c|c|c|c|c|}
\hline & Base money & $M_{2}$ & $r 1 \%$ & $k$ & $r 2 \%$ & $r 2 / r 1$ \\
\hline 1999 & 29798.2 & 11763.81 & 12.57 & 3.9478 & & \\
\hline 2000 & 31957.34 & 13248.75 & 12.62 & 4.1458 & 0.26 & 0.021 \\
\hline 2001 & 33957.84 & 15288.85 & 15.40 & 4.5023 & 0.46 & 0.030 \\
\hline 2002 & 37727.45 & 18324.69 & 19.86 & 4.8571 & -0.77 & - \\
\hline 2003 & 43798.52 & 21922.68 & 19.63 & 5.0053 & 1.16 & 0.059 \\
\hline 2004 & 58776.79 & 25320.77 & 15.50 & 4.3080 & 3.89 & 0.251 \\
\hline 2005 & 64245.22 & 29875.55 & 17.99 & 4.6502 & 1.82 & 0.101 \\
\hline 2006 & 77597.96 & 34557.79 & 15.67 & 4.4534 & 1.46 & 0.093 \\
\hline 2007 & 101387.4 & 40340.13 & 16.73 & 3.9788 & 4.75 & 0.284 \\
\hline Mean & & & & 4.4876 & & 0.120 \\
\hline
\end{tabular}

Source: the World Bank "World Development Indicators" (WDI) (from Annual Book of World Economy 2008-2009).

of intervention is a stable and improved economy and society of the country, which is judged by the level of the country's sovereign credit.

There is substantial difference between country's profits when this country has either a good sovereign credit level or a better credit level. Here we use the assessment levels of some famous international credit rating agencies, such as Moody. Assuming that two companies having different assessment levels, namely, Aaa and Baa, have different funding costs in the market due to the different assessment levels by Moody, this difference of funding costs is defined as the profit of the sovereign credit rating. Figure 3(a) gives the funding cost of these two companies with either Aaa or Baa rating. The difference of the funding cost is given in Figure 3(b), whose averaged value over 1990 to 2008 is 0.117 . This value is termed the yield of the sovereign credit rating in this work.

3.3. Profit of Buying Interest-Bearing Assets. One of the three principles of managing foreign exchange reserve is to ensure its safety. Thus, a country usually invests the reserves in some credit instruments, such as government bonds or stateguaranteed corporate bonds with high credibility. From the point of view of liquidity, short-term government bonds have stronger liquidity than other types of bonds, then followed by medium and long-term government bonds or reputable corporate bonds. Investing reserves in such bonds, especially in short-term government bonds, can ensure a certain degree of liquidity and obtain appropriate benefits as well. Therefore, the interest income on purchasing interest earning assets is one type of profit of holding foreign exchange reserve. In China, foreign exchange reserves are denominated in US dollars for the purchase of US interest-bearing assets such as high-quality bonds, and we analyze the revenue based on the purchase of US government bonds and US corporate bonds.

3.3.1. Purchases of US Government Bonds. According to data released by the US Treasury Department, China's holdings of US government bonds reached US\$727.4 billion in 2008 (Figure 4(a)). From the data in Figure 4(b), the proportion of China's foreign exchange reserve for US government 


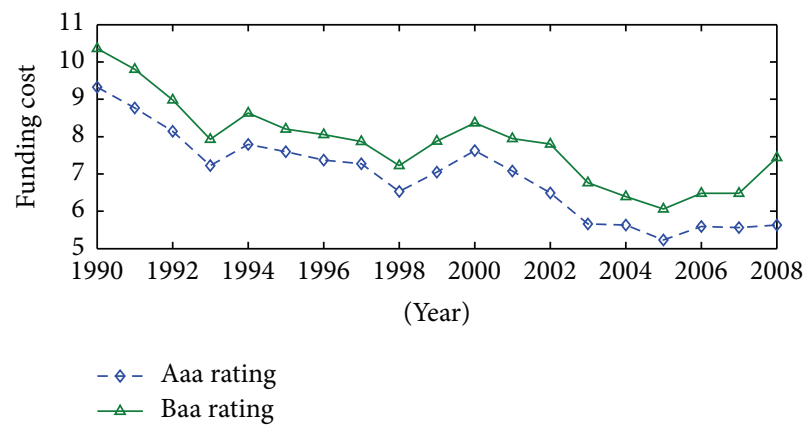

(a)

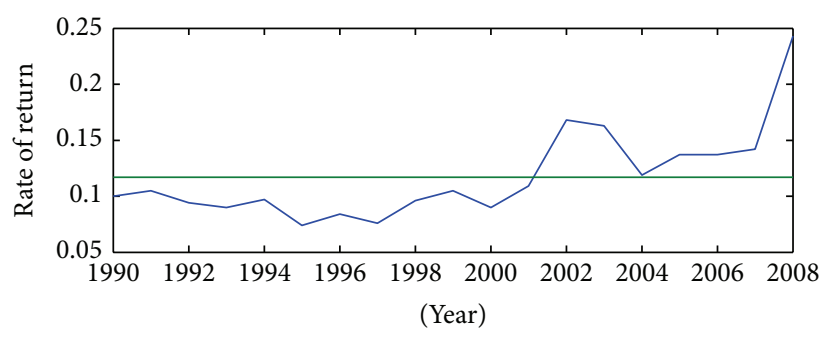

(b)

FIGURE 3: Analysis of yield of two companies having different credit ratings. (a) The funding cost of two companies. (b) Yield due to the different credit ratings. The horizontal line is the averaged value, 0.117.

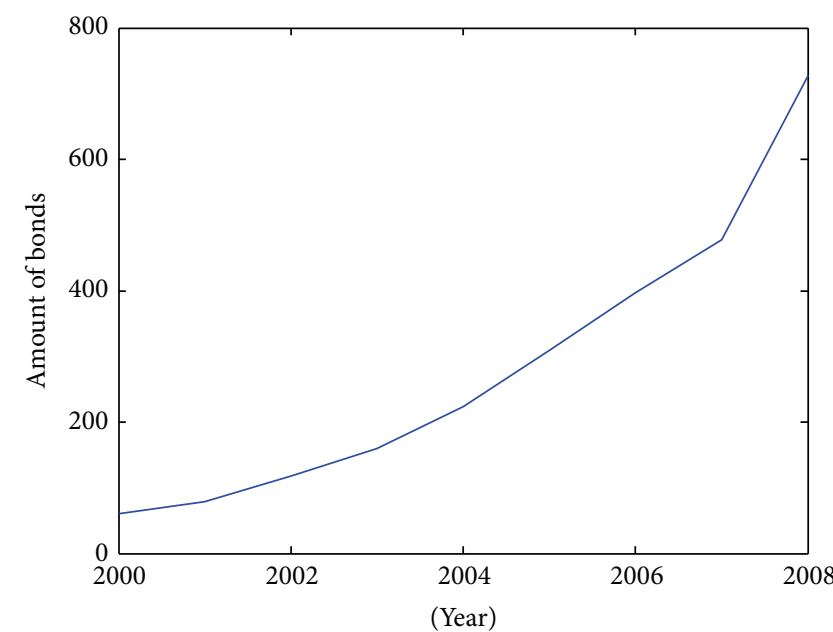

(a)

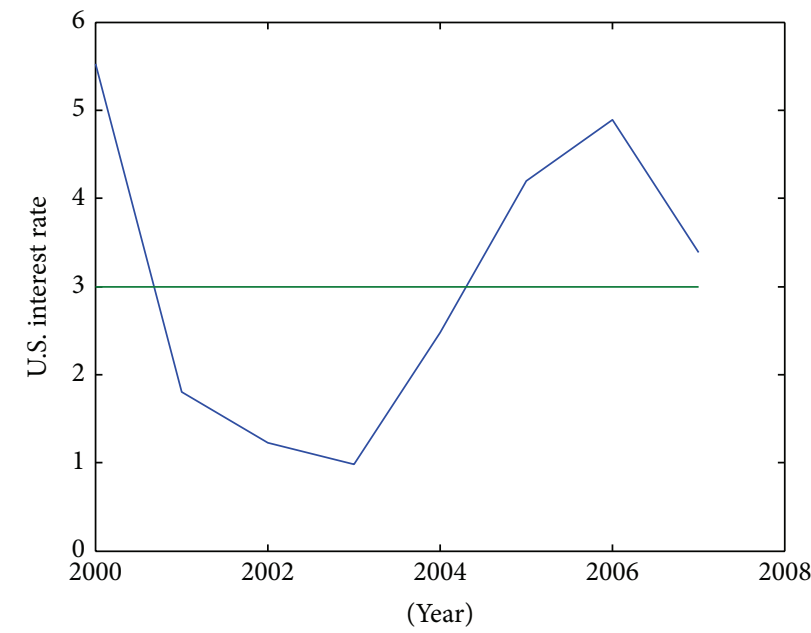

(c)

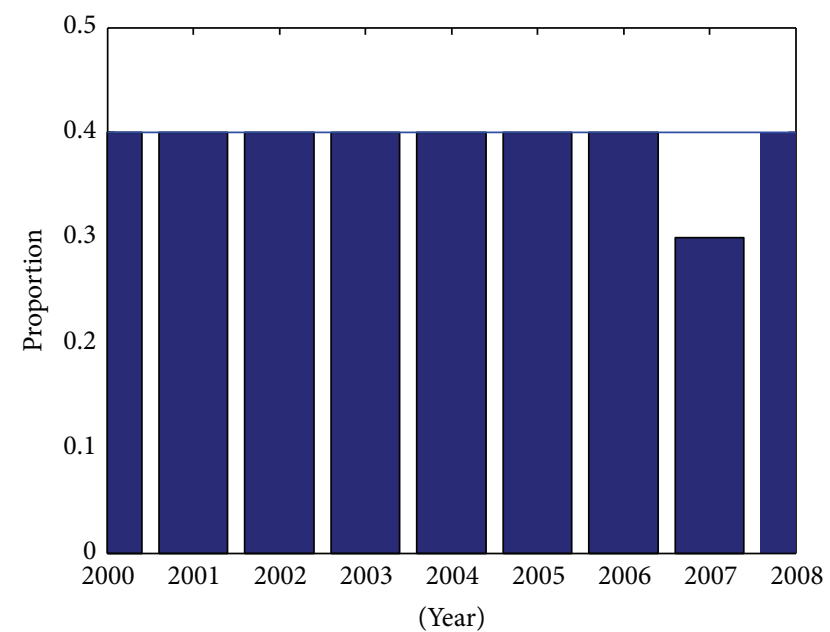

(b)

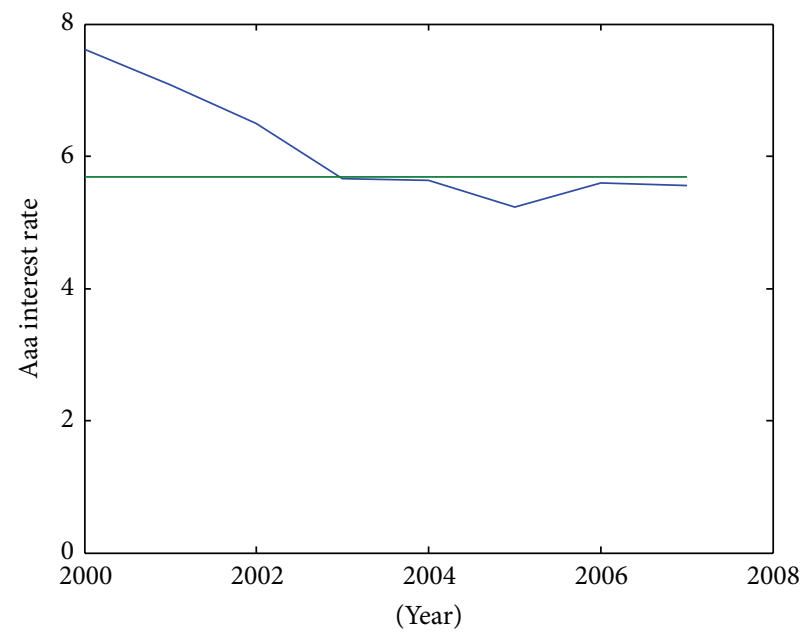

(d)

FIgURE 4: Analysis of China's purchase of US bonds. (a) The amount of purchased bonds (unit: billion). (b) Proportion of foreign exchange reserve for buying the bonds (averaged value: 0.4 , the horizontal line). (c) Interest rates of 6-month US government bonds (averaged value: 3, the horizontal line). (d) Interest rate of corporate bonds with Aaa rating (averaged value: 5.69, the horizontal line). 
bonds was always around 40\% from 2000 to 2008 . The only exception is the proportion of $30 \%$ in 2007 . Thus, we use the value of $40 \%$ in the majority of this time period for the proportion of reserves for government bonds. For the yields of purchasing US government bond, since the Chinese government mainly bought short-term investments, our study primarily uses the interest income of 6-month US government bonds whose rate is given in Figure 4(c). During that time period, the bond rates reached the highest value of $5.53 \%$ in 2000 and the lowest value of $0.98 \%$ in 2003 . The averaged rate is $3 \%$ during that time period.

3.3.2. Purchases of US Corporate Bonds. According to the previous analysis in this work, a proportion of $23 \%$ of China's foreign exchange reserves is prepared for the demand of productive investment, and the $17 \%$ of the reserves are used to meet the intervention demand. Thus, the remaining $60 \%$ of the reserves are for the purchase of interest-bearing assets, among which $40 \%$ of the reserves are for the purchase of US government bonds. So we assume that the $20 \%$ of the reserves are used to buy the US corporate bonds.

Here we use credit rating agency Moody's data for utility bonds and Aaa-rated industrial bonds to analyze assessment results (Figure $4(\mathrm{~d})$ ). Since the interest rate data prior to December 2001 had both Aaa-rated utility bond and industrial bonds but after December 2001 there was only interest rates data of industrial bonds, we used the interest rates data during 2002-2007 to calculate the averaged annual interest rates, which is $5.69 \%$. In addition, we consider three types of bond length, namely, short, intermediate, and long term. The averaged rate is based on the rates of these three types of bonds. Since the primary concern of holding the reserves is the safety, especially for the stabilization of foreign exchange market, the majority of investment should be short term. Thus, the averaged interest rate should be reduced proportionally from the annual interest rate which is for the longterm assets. However, by taking the sufficiency of Chinese current foreign exchange reserves into account, liquidity should be less concerned. The downward adjustment would not be too large. In this work, we adjust the averaged yield from $5.69 \%$ down to $5 \%$, in order to reflect the purpose of risk management for foreign exchange reserves.

\section{Model and Prediction}

4.1. The Market Theory. The market theory is to study the rational allocation of resources by the performance of firm [15]. It is assumed that the aim of each firm is to achieve the maximal profit through production and sales activities. Theoretically the maximal profit is determined directly by the related marginal costs and marginal profits. Here the marginal cost is that for the production of the final unit product, while the marginal profit is that for the sale of the final unit product. In the market theory, if the marginal profit is more than the marginal cost, the firm will continue to increase the production for increasing the gross profit. However, if the marginal profit is less than the marginal cost, the firm will reduce production, because the increase of production will not increase the profit, but rather it will result in profit losses. Thus, in theory when the marginal profit equals the marginal cost, the gross profit of the firm will achieve the maximum. This profit of the firm can be mathematically represented by

$$
\pi(Q)=\mathrm{TB}(Q)-\mathrm{TC}(Q),
$$

where $Q$ is the production, $\pi$ is the profit, TB is the gross profit, and TC is the gross cost. The necessary condition for profit maximization is that the first derivative of profit $\pi$ to the production $Q$ is zero; that is,

$$
\begin{aligned}
\frac{d \pi(Q)}{d Q} & =\frac{d \mathrm{~TB}(Q)}{d Q}-\frac{d \mathrm{TC}(Q)}{d Q}=0, \\
\frac{d \mathrm{~TB}(Q)}{d Q} & =\frac{d \mathrm{TC}(Q)}{d Q} .
\end{aligned}
$$

So the first derivative of TB to $Q$ is the marginal profit, and the first derivative of TC to $Q$ is the marginal cost. When the marginal profit equals the marginal cost, it is the necessary condition for profit maximization.

Since the 1960s, this market theory has been applied to analyze the scale of country's foreign exchange reserves, which is represented by the work of Agarwal [16]. In summary, when the marginal profit is larger than the marginal cost for holding the foreign exchange reserves, the country can increase their holdings to help improve the economy. On the contrary, when the marginal profit is less than the marginal cost, the country should reduce the holdings, because the economy will decline due to holding too much foreign exchange reserves. Thus, only when the marginal profit equals the marginal cost, the country will get the maximal social welfare and the holding of the foreign exchange reserve will be the optimal scale. In this work, we will use this market theory to analyze the optimal scale of China's foreign exchange reserves.

4.2. Model Development. When using the market theory to analyze the scale of China's foreign exchange reserve, we first need to determine the structure of costs and profits of holding the reserves. Then, we can determine the optimal scale of foreign exchange reserves by letting the marginal cost equal the marginal profit. According to the analysis in Section 3, there are two types of cost of holding the foreign exchange reserves, namely, the cost of interest loss and cost of exchange rate. In addition, the main revenue of holding the reserves constitutes three major aspects. They are the profit of productive investment, gain of intervention in response to the need, and the income of buying interest-bearing assets. Thus, the mathematical model can be developed as follows.

First, the gross cost $C$ of holding the reserves is

$$
C=C_{1}+C_{2}
$$

where $C_{1}$ is the cost of interest loss and $C_{2}$ is the cost of exchange rate. In addition, the gross revenue $B$ of holding the reserves is

$$
B=B_{1}+B_{2}+B_{3} \text {, }
$$


where $B_{1}$ is the income of purchasing the interest-bearing assets, $B_{2}$ is the income of productive investment, and $B_{3}$ is the gain of intervention in response to the need.

In particular, the cost of interest loss is

$$
C_{1}=R * i_{1},
$$

where $R$ is the scale of foreign exchange reserves in Figure 2(a) and $i_{1}$ is the interest rate of Euro-dollar's 3-month deposit (e.g., 3.574\% in Figure 1(a)). In addition, the cost of exchange rate is

$$
C_{2}=R * \Delta e,
$$

where $\Delta e$ is the depreciation rate of the US dollar to Chinese $\mathrm{RMB}, 8 \%$ in Table 1.

Regarding the revenue, the income of purchasing the interest-bearing assets is

$$
B_{1}=R * \rho_{1} * i_{2}+R * \rho_{2} * i_{3},
$$

where $\rho_{1}$ is the proportion of foreign exchange reserve to invest US government bonds, 0.4 , whose interest rate $i_{2}$ is $3 \%$; $\rho_{2}$ is the proportion to invest US corporate bonds, 0.2 , whose interest rate $i_{3}$ is $5 \%$.

The income of productive investment $B_{2}$ is represented by

$$
B_{2}=R * \rho_{3} * \sigma * \mu,
$$

where $\rho_{3}$ is the proportion of the reserves in productive investment spending, 0.23 ; $\sigma$ is the rate of return on investment, 0.283; and $\mu$ is adjustment factor of the investment rate of return based on the domestic inflation rate (1). In the adjustment factor, $v$ is the ratio of domestic inflation rate to broad money supply $M_{2}, 0.12 ; e$ is the foreign exchange rate in Table $1 ; k$ is the money multiplier, 4.4876; and $M_{2}$ is the broad money supply in Table 3.

Finally, the gain of intervention in response to the need is

$$
B_{3}=R * \rho_{4} * \varphi,
$$

where $\rho_{4}$ is proportion for intervention spending in response to demand, 0.17; and $\varphi$ is yield of intervention in response to demand, 0.227.

Based on the identified factors above, the marginal cost of holding reserves is defined by

$$
\frac{d C(R)}{d R}=\frac{d\left(R * i_{1}+R * \Delta e\right)}{d R}=i_{1}+\Delta e,
$$

and the marginal profit of holding reserves is represented by

$$
\begin{aligned}
\frac{d B(R)}{d R} & =\frac{d\left(B_{1}+B_{2}+B_{3}\right)}{d R} \\
& =\rho_{1} i_{2}+\rho_{2} i_{3}+\rho_{3} \sigma+\rho_{4} \varphi+2 R \rho_{3} \sigma v e \frac{k}{M_{2}} .
\end{aligned}
$$

Thus, the optimal scale of foreign exchange reserve can be determined by the equal of marginal cost to the marginal profit (3); namely,

$$
i_{1}+\Delta e=\rho_{1} i_{2}+\rho_{2} i_{3}+\rho_{3} \sigma+\rho_{4} \varphi+2 R \rho_{3} \sigma v e \frac{k}{M_{2}},
$$

TABLE 4: Real foreign exchange reserve (FER) and predicted FER.

\begin{tabular}{lcc}
\hline & Real FER & Predicted FER \\
\hline 1999 & 154.675 & 179.583 \\
2000 & 165.574 & 202.251 \\
2001 & 212.165 & 233.395 \\
2002 & 286.407 & 279.739 \\
2003 & 403.251 & 334.665 \\
2004 & 609.932 & 386.539 \\
2005 & 818.872 & 461.083 \\
2006 & 1066.34 & 548.068 \\
2007 & 1528.249 & 670.038 \\
2008 & 1946.03 & 864.188 \\
\hline
\end{tabular}

which gives the optimal foreign exchange reserves as

$$
R=\frac{M_{2}}{2 \rho_{3} \sigma v e}\left[i_{1}+\Delta e-\left(\rho_{1} i_{2}+\rho_{2} i_{3}+\rho_{3} \sigma+\rho_{4} \varphi\right)\right] .
$$

4.3. Model Predictions. Using data of the Chinese broad money supply in Table 3 and exchange rate in Table 1 , together with the identified factor values in Section 4.2, we calculate China's optimal foreign exchange reserves in the time period of 1999 to 2008 using the derived model (15). The predicted optimal foreign exchange reserve and real foreign exchange reserve are presented in Table 4. Our prediction suggested that China's foreign exchange reserves were still within the moderate range in 1999-2001. However, during 2002-2008 the foreign exchange reserve began to exceed the appropriate scale, and this upward trend was accelerated each year. In addition, China's foreign exchange reserves began to exceed the optimal scale for more than one time since 2007. Since the scale of China's foreign exchange reserves is in a state of excessiveness over the optimal scale, the expanding cost of hosting reserve has substantially declined the potential profit that may derive from the foreign reserve, which is in the contrary to the purpose of international trading, namely, to increase the level of social welfare and people's revenue.

Thus, the Chinese State Administration of Foreign Exchange should adjust the amount of the current reserves, especially in facing the challenges and opportunities of the 2008 global financial crisis, increase the foreign capitals through other financial means, and explore new ways to foreign economic and political exchanges. These approaches will improve the current situation of excessive foreign exchange reserves as well as opening up new areas to improve the country's international status.

\section{Conclusions}

In this work we used the cost-profit model to estimate the optimal scale of China's foreign exchange reserve. The main contribution of this work includes the classification of financial factors that are related to either the cost or profit of holding the reserves. Using financial data between 2000 and 2008, we made predictions about the optimal foreign exchange reserve during that time period. Our predictions suggested that China's foreign exchange reserves were still 
within the moderate range in 1999-2001. However, during 2002-2008 the foreign exchange reserve began to exceed the appropriate scale, and this upward trend was accelerated each year. The major limitation of the proposed model is the selected values of costs and benefits, especially the values to determine the income for dealing with the needs of intervention. In addition, when we consider intervention to stabilize the economy, the proportion of foreign exchange reserves is primarily determined by the data of Hong Kong's market during the Asian financial crisis in 1997. Updated values for the time period before 2008 will improve the accuracy of prediction.

Since the global financial crisis in 2008, the situation of China's foreign exchange reserve has changed significantly. Thus, the linear model used in this work is not appropriate to analyze the most recent data. Thus, our next step is to develop nonlinear models to evaluate the optimal scale of China's foreign exchange reserve in recent year.

\section{Competing Interests}

The authors declare that there are no competing interests regarding the publication of this paper.

\section{Acknowledgments}

Xing Li thanks Zhongnan University of Economics and Law for the support of the Research and Funding for Youth. Tianhai Tian is also supported by grants from the Australian Research Council (FT100100748 and DP120104460). This research work is supported by the National Natural Science Foundation of China (11571368).

\section{References}

[1] K. P. Prabheesh, "Optimum international reserves and sovereign risk: evidence from India," Journal of Asian Economics, vol. 28, pp. 76-86, 2013.

[2] D. Rodrik, "The social cost of foreign exchange reserves," International Economic Journal, vol. 20, no. 3, pp. 253-266, 2006.

[3] J. Aizenman and N. Marion, "International reserves: precautionary versus mercantilist views, theory and evidence," Open Economies Review, vol. 18, no. 2, pp. 191-214, 2007.

[4] O. Jeanne and R. Rancière, "The optimal level of international reserves for emerging market countries: a new formula and some applications," The Economic Journal, vol. 121, no. 555, pp. 905-930, 2011.

[5] Z. Ma, Research on Developing Countries about the Demand for Foreigh Exchange Reserve, East China Normal University Press, Shanghai, China, 1994.

[6] S. Guo, "Several important problem about China's present foreigh exchange reserve," China Finance 7, 2005.

[7] Y. Li, China's View of Foreign Exchange Reserve Is Outdated, The Renmin University of China Copies, Finance and Insurance, Beijing, China, 2003.

[8] F. Chen and H. Zou, "China's optimal foreign reserve: quantitative characteristics, motivation decomposition and adjustment speed," Economic Review, vol. 5, pp. 103-111, 2012.

[9] R. Triffin, Gold and the Dollar Crisis, Yale University Press, London, UK, 1960.
[10] G. A. Calvo, "Capital flows and macroeconomic management: tequila lessons," International Journal of Finance and Economics, vol. 1, no. 3, pp. 207-223, 1996.

[11] O. Jeanne, "International reserves in emerging market countries: too much of a good thing?" Brookings Papers on Economic Activity, vol. 38, no. 1, pp. 1-80, 2007.

[12] H. R. Heller, “Optimal international reserves," The Economic Journal, vol. 76, no. 302, pp. 296-311, 1966.

[13] M. D. Dooley, D. Folkerts-Landau, and P. Garber, "An essay on the revised Bretton Woods System," NBER Working Paper 9971, 2003.

[14] M. Feldstein, "Self-protection for emerging market economies," NBER Working Paper 6907, 1999.

[15] N. Saidi, “The square-root law, uncertainty and international reserves under alternative regimes: Canadian experience, 19501976," Journal of Monetary Economics, vol. 7, no. 3, pp. 271-290, 1981.

[16] J. P. Agarwal, "Optimal monetary reserves for developing countries," Review of World Economics, vol. 107, no. 1, pp. 7691, 1971. 


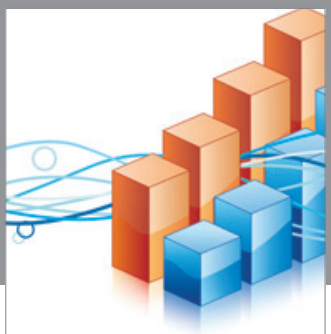

Advances in

Operations Research

vatem alat4

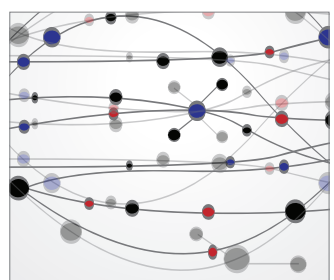

\section{The Scientific} World Journal
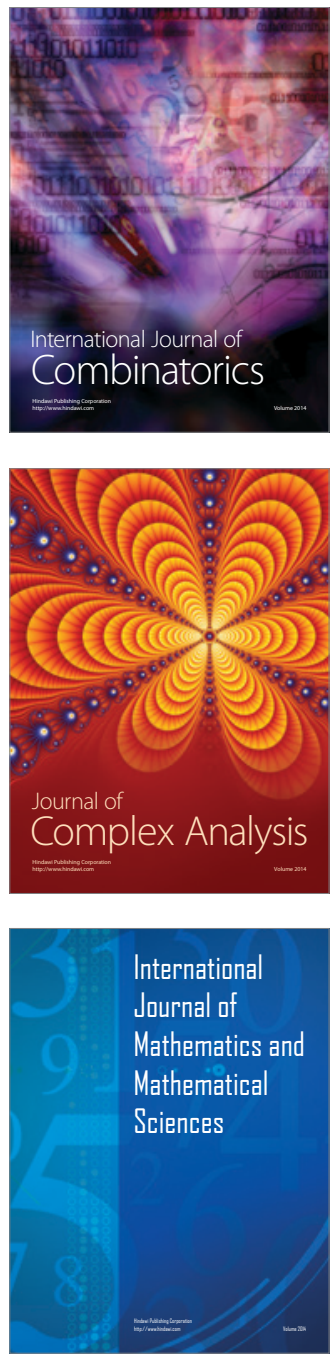
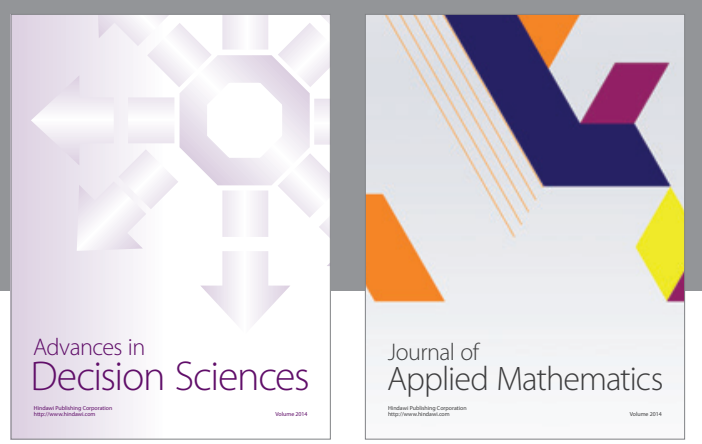

Algebra

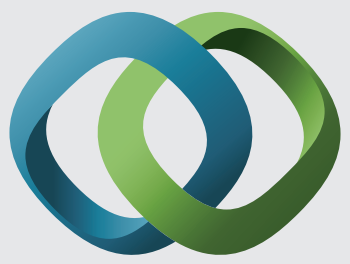

\section{Hindawi}

Submit your manuscripts at

http://www.hindawi.com
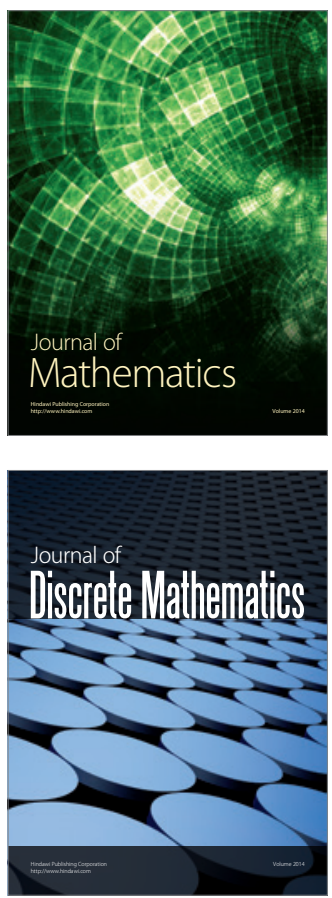

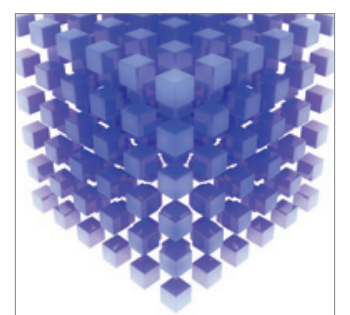

Mathematical Problems in Engineering
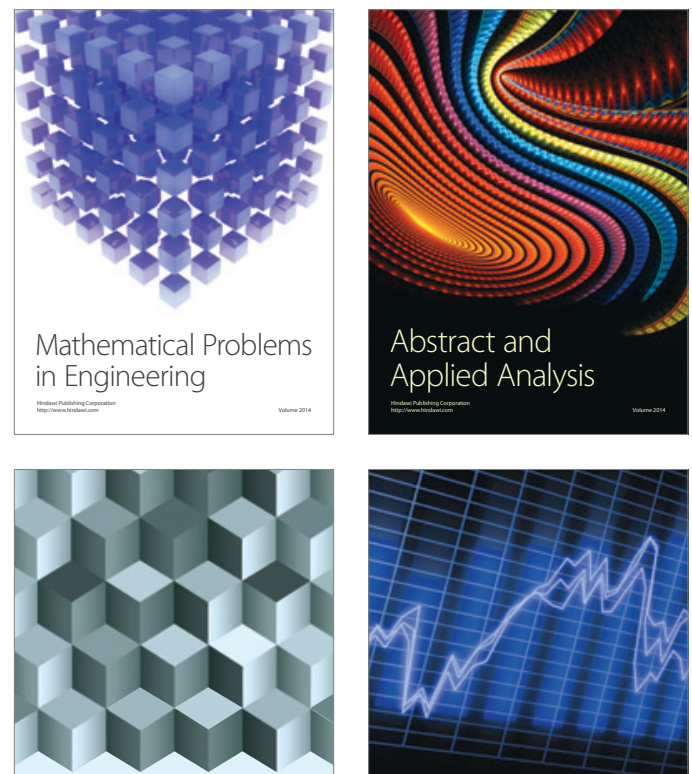

Journal of

Function Spaces

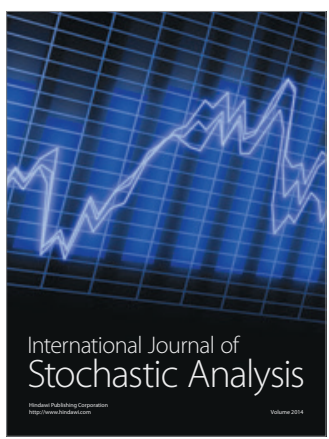

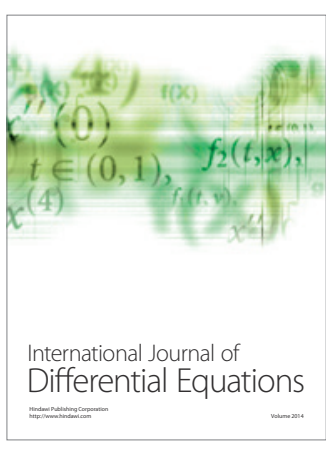
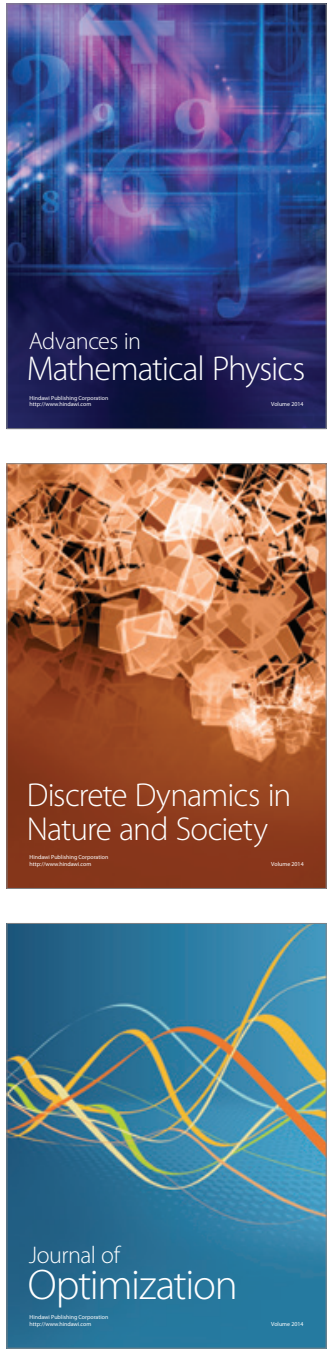